\title{
Safety and Efficacy of Aneurysm Treatment with the WEB
}

W e read with interest the article by Pierot et $\mathrm{al}^{1}$ regarding the results of the WEBCAST 2 study. We do, however, take issue with the statement that it confirms the "high" efficacy of the device. They reported a complete occlusion rate of 54\% and "adequate" occlusion, including neck remnants, in $80 \%$ of 50 aneurysms (93\% unruptured). The complete occlusion rate from neurosurgical clipping in the largest randomized controlled trials of coiling versus clipping of ruptured aneurysms was 96\%., $\mathrm{A}$ meta-analysis of clipping of unruptured aneurysms showed a complete occlusion rate of $92 \% .{ }^{4}$ Although the decision to proceed with endovascular therapy in WEBCAST was made by a multidisciplinary team, it may be wise to temper one's enthusiasm for novel endovascular devices when open neurosurgical treatment may offer a truly "high" level of efficacy.

http://dx.doi.org/10.3174/ajnr.A5387

\section{REFERENCES}

1. Pierot L, Gubucz I, Buhk JH, et al. Safety and efficacy of aneurysm treatment with the WEB: results of the WEBCAST 2 study. AJNR Am J Neuroradiol 2017;38:1151-55 CrossRef Medline

2. Spetzler RF, McDougall CG, Zabramski JM, et al. The Barrow Ruptured Aneurysm Trial: 6-year results. J Neurosurg 2015;123:609-17 CrossRef Medline

3. Campi A, Ramzi N, Molyneux AJ, et al. Retreatment of ruptured cerebral aneurysms in patients randomized by coiling or clipping in the International Subarachnoid Aneurysm Trial (ISAT). Stroke 2007; 38:1538-44 CrossRef Medline

4. Kotowski M, Naggara O, Darsaut TE, et al. Safety and occlusion rates of surgical treatment of unruptured intracranial aneurysms: a systematic review and meta-analysis of the literature from 1990 to 2011. J Neurol Neurosurg Psychiatry 2013;84:42-48 CrossRef Medline

(1)D.M. Pelz (iD.P. Lownie Departments of Medical Imaging and Clinical Neurological Sciences Schulich School of Medicine and Dentistry, Western University London, Ontario, Canada 